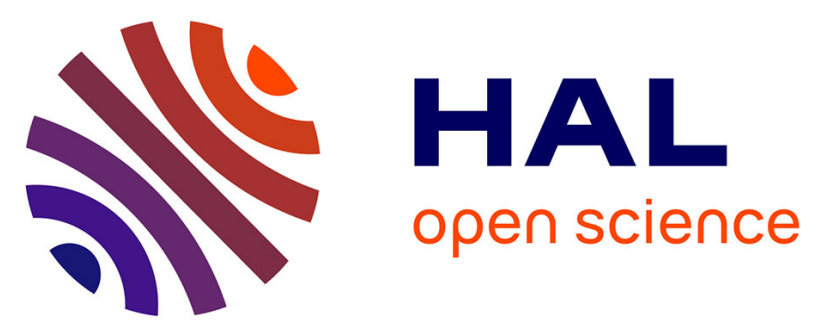

\title{
Continental weathering using combined Hf-Nd isotope system and clay mineralogy: new insights for the Late Cretaceous climate
}

Pauline Corentin, Emmanuelle Puceat, Pierre Pellenard, Nicolas Freslon, Michel Guiraud, Justine Blondet, Thierry Adatte, Germain Bayon

\section{To cite this version:}

Pauline Corentin, Emmanuelle Puceat, Pierre Pellenard, Nicolas Freslon, Michel Guiraud, et al.. Continental weathering using combined Hf-Nd isotope system and clay mineralogy: new insights for the Late Cretaceous climate. vEGU21: Gather Online, Apr 2021, Online, France. 10.5194/egusphereegu21-11995 . hal-03554524

\section{HAL Id: hal-03554524 \\ https://hal.science/hal-03554524}

Submitted on 3 Feb 2022

HAL is a multi-disciplinary open access archive for the deposit and dissemination of scientific research documents, whether they are published or not. The documents may come from teaching and research institutions in France or abroad, or from public or private research centers.
L'archive ouverte pluridisciplinaire HAL, est destinée au dépôt et à la diffusion de documents scientifiques de niveau recherche, publiés ou non, émanant des établissements d'enseignement et de recherche français ou étrangers, des laboratoires publics ou privés. 
EGU21-11995

https://doi.org/10.5194/egusphere-egu21-11995

EGU General Assembly 2021

(c) Author(s) 2022. This work is distributed under

the Creative Commons Attribution 4.0 License.

\title{
Continental weathering using combined Hf-Nd isotope system and clay mineralogy: new insights for the Late Cretaceous climate
}

\author{
Pauline Corentin ${ }^{1}$, Emmanuelle Puceat ${ }^{1}$, Pierre Pellenard ${ }^{1}$, Nicolas Freslon ${ }^{2}$, Michel Guiraud ${ }^{1}$, \\ Justine Blondet ${ }^{1}$, Thierry Adatte ${ }^{3}$, and Germain Bayon ${ }^{4}$ \\ ${ }^{1}$ Université de Bourgogne Franche-Comté, Laboratoire Biogéosciences, Dijon, France (pauline.corentin@u-bourgogne.fr) \\ ${ }^{2}$ CNRS - Université - ISTO Campus Géosciences, 45071 Orléans - France \\ ${ }^{3}$ Institute of Earth Sciences, Géopolis, University of Lausanne, Lausanne, Switzerland \\ ${ }^{4}$ IFREMER, Unité de Recherche Géosciences Marines, F-29280 Plouzané, France
}

The Late Cretaceous period records a pronounced decrease in marine temperatures at a global scale initiating the last greenhouse-icehouse transition, whose origin still remains enigmatic. Continental weathering represents a major sink of atmospheric $\mathrm{CO}_{2}$ through silicate weathering reactions yet the importance of this process in the Late Cretaceous cooling has only been scarcely explored.

In this study we explore the impact of the eastern South American margin uplift, concomitant to the long-term Late Cretaceous cooling, on the evolution of chemical weathering of the Brazilian margin, using a new proxy of silicate weathering based on the coupled Lu-Hf and Sm-Nd isotope systems in clays. This proxy, expressed as $\Delta \varepsilon_{\mathrm{Hf}}$, has been recently calibrated in modern environments (Bayon et al., 2016) but has only been scarcely applied to deep-time environments. This proxy, applied on sediments from DSDP site 356 on the São Paulo Plateau, highlights a marked increase in silicate chemical weathering of the southeastern Brazilian margin from the Santonian to the Maastrichtian, also supported by the evolution of the chemical index of alteration (CIA) and clay mineralogy.

This increase follows an episode of enhanced mechanical erosion of the margin revealed in the Turonian to Santonian by an increase of primary clay mineral (illite, chlorite) and Ti/Al ratio, linked to the tectonic uplift of the margin. Clay mineral assemblages additionally point to an evolution of local climatic conditions from arid to a more hydrolysing climate following this episode, that we link to a "rain shadow effect" affecting the eastern side of the newly formed relief that would have enhanced chemical weathering of the margin.

Importantly the temporal coincidence of the increase in chemical weathering depicted here with the marked acceleration of the global cooling recorded worldwide during the Campanian points to a potentially important role of this process on the overall climate decline initiating the descent into our icehouse climate mode. Although records from additional sites are needed to establish the spatial extent of the margin affected by this process, our new dataset brings new insights about the impact of tectonic forcing on climate. 
Bayon et al. (2016) EPSL 438, p. 25-36. 